Journal of Humanities, Social and Management Sciences (JHSMS)

eISSN: 2788-4791 (online)

https:// doi.org/10.47264/idea.jhsms/3.1.5

Vol. 3, No. 1 (January-June 2022), 57-70

https://ideapublishers.org/index.php/jhsms

Research Article

\title{
Sinophobia in the semiotic representation of Covid-19 in English language newspapers
}

\author{
Shahzad Nabi* \\ Department of English Language and Literature, The University of Lahore, Pakistan. \\ *Corresponding Author Emails: shahzad.nabi@ell.uol.edu.pk \\ Received: December 6, $2021 \quad$ Accepted: February 1, $2022 \quad$ Published: February 25, 2022
}

\begin{abstract}
This study examines use of semiotic resources, deployed by selected English language newspapers to describe a discourse of Sinophobia in the first wave of Covid-19. It explores how was the discourse of Sinophobia (anti-Chinese sentiments) expressed by highly circulated English language newspapers in the world? The data was based on 10 editorial articles of four English language newspapers: "The New York Times, The Guardian, The Tribune, and The Japan Times". In addition, 30 participants' perceptions about the semiotic choices used by these newspapers were studied to support the findings from selected editorials. Public comments were taken on the notion that they should talk about China and the role of Chinese people in spreading Covid-19. The data was interpreted through thematic analysis by codifying the emerging discursive themes. The findings reveal that semiotic resources deployed by the selected English language newspapers created a discourse of Sinophobia as the data laid great stress on the emergence of virus in the City of Wuhan, China. Moreover, the use of semiotic resources by the English language newspapers is replicated by the participants, as the language of the newspapers and participants on these semiotic resources surface positive self-claim and negative out-group. They divide between them and us, have and have not, eventually widened the language of fear, panic, and hatred.
\end{abstract}

Keywords: Sinophobia, Covid-19, Semiotics, English language newspapers, thematic analysis, discourse, fear.

\section{How to Cite:}

Nabi, S. (2022). Sinophobia in the semiotic representation of Covid-19 in English Language Newspapers. Journal of Humanities, Social and Management Sciences (JHSMS), 3(1), 57-70. https://doi.org/10.47264/idea.jhsms/3.1.5

Publisher's Note: IDEA PUBLISHERS (IDEA Publications Group) stands neutral with regard to jurisdictional claims in the published maps and institutional affiliations.

Copyright: @ 2022 The Author(s), published by IDEA PUBLISHERS (IDEA Publications Group).

Licensing: This is an Open Access article published under the Creative Commons AttributionNonCommercial 4.0 International License (http://creativecommons.org/licenses/by-nc/4.0/) 


\section{Introduction}

With the outbreak of Covid-19, the world was undergoing a great recession in terms of health crisis, financial management, and social or domestic catastrophes, where the role of media especially newspapers had become more significant because of their wide-reaching readers. Journalists started covering Covid-19 in bizarre linguistic terms and disturbing images of death, fear and xenophobia. The selection of semiotic tools including words, pictures, images, symbols, and videos perpetuates a certain kind of discourse and affects how people should interpret an event (Kress \& Van Leeuwan, 1996). This study assumes that English language newspapers have contributed towards xenophobia especially Sinophobia through semiotic choices. The fear of the novel Coronavirus gives birth to anti-Chinese sentiments mainly when it was reported that the outbreak was started from Wuhan, after that the country is under great criticism of producing the virus. After the emergence of the virus and its spread all over the world, Jutland post has posted the Chinese flag with certain additions that created the impression that the virus originated in China. In the same way, Reuters posted a sign of a nail shop in Phu Quoc, which asked a ban on Chinese entry into the shops. The Wall Street Journal named China as 'the sick man of Asia', Der Spiegel named the Coronavirus made in China, Washington Post called it a Chinese bioweapon, and The Daily Times called it as the result of the Chinese eating habits of bats and others. In Japan, there was a twitter trend with the hash tag \#ChineseDontCometoJapan to ban the Chinese and their products.

On $30^{\text {th }}$ January 2020, an article published in NY Times with its title 'As Coronavirus Spreads, So Does Anti-Chinese Sentiment', that recommended differentiating between 'understandable fear' and 'unmistakable discrimination'. It is not always easy to draw a line between understandable fear and unmistakable discrimination. During the first wave of Covid-19, there was an increase in unmistakable discrimination against the Chinese. A restaurant owner in central Hoi posted a flashcard "We cannot service for Chinese, SORRY!". France regional newspaper 'Le Courrier Picard' issued a yellow alert to increase racial discrimination in Europe, for which they later apologized. The State Department of The United States of America asked its citizen to forbid travelling to China and the Government of Pakistan asked its students to stay in China as they could carry the virus along with them. A trending video on YouTube in South Korea claimed that a biochemical weapon has leaked from China. In Sydney, people were compelled to stop purchasing Chinese Red Bull, cookies, and rice through a fake post on Instagram. A Vietnamese Woman reported to Le Monde newspaper that she got discriminatory remarks from his driver, who yelled "Keep your virus, dirty Chinese!" The Chinese government also proved to be the stimulator of such responses for the Chinese all over the world, as they were treating the Chinese inside China very differently.

However, the concern of this research paper is to analyse the semiotic choices of the selected English language newspapers in the world and the people who have commented under the selected articles of the international English language newspapers. The Research questions of the study are: (a) how discourse of Sinophobia was expressed by the semiotic resources of selected English language newspapers while reporting the Covid-19? and (b) what was the reaction of the public who commented online on the semiotic resources of the selected English language newspaper articles? This paper contributes to the studies on the discourse of Sinophobia created by media to serve political interests. This study recommends replacing the current semiotic choices used by the media with neutral, honest, and positive lexical and visual choices. The discourse of Sinophobia should be replaced with the discourse of medical officials 
that should use factual language and show optimistic visuals to build policies for the most vulnerable in the world.

\section{Literature review}

The history of pandemics tests our mutual and intellectual consciences. We are living in a society, where discrimination and prejudice are considered immoral or sometimes illegal (Van Dijk, 1991). The spread of the Covid-19 from the city of Wuhan has embarked an upsurge of xenophobia especially anti-Chinese sentiments and stirred inhospitable views for the Chinese community all over the world (Mahr, 2020, Rafi, 2020). The role of print media remains important in such abnormal situations because of their wide-reaching readers as supported by Marko (2013). The use of semiotic tools in media propagates a particular discourse about an event and marks how people should interpret an event where words, pictures, images, symbols, and videos are used to achieve certain effects (Kress \& Van Leeuwen, 1996; Van Dijk, 2009). Fear-provoking images of patients, deaths and viruses promote bizarre linguistic terms in the media such as quarantine, lockdown and shutdown that created fear of others (xenophobia) and eventually anti sentiments for the Chinese government and its people (Rafi, 2020: Zheng et al., 2020; Zhao, 2020; Yong, 2020). Marko (2013) showed in his research how fear originates from blaming a particular community, which leads to a 'risk society'. We have witnessed a superpower like China has become a 'risk society' in a matter of few days after the outburst of the Covid-19 as the State Department of The United States of America asked its citizen to forbid traveling to China.

Mahr (2020) tried to explore the reasons for Trump's call of the Covid-19 as a 'Chinese Virus'. She claimed that Trump's media consumption led him to call the virus a Chinese virus. She claims that words and images used to describe the virus are perpetuating problematic suppositions about China and the Chinese community all over the world as she has shown how the Chinese culture and its eating customs were targeted before the scientists could fix the origin of the virus outbreak. Marko (2013) exhibits, not all threats are real; some are created and aggravated by social agents. Media has a socio-political potential to define and provoke scope of fear as referred by Corradi et al. (1992), who argue that political order without fear is the 'unattainable utopia'. The fear of otherness, especially xenophobia, in terms of threats to nationalism, affects the interpretation and the way an event is presented and framed in media. Albader (2020) studies state responses that perpetuated fear and eventually Sinophobia. He believes that states were contributing to civil turmoil, especially xenophobia in an ongoing pandemic that compelled states and people to act in an unconventional way initiating inner disruptions. Further, he claims during the emergency against the spread of the Covid-19, statelevel responses only increased the sentiments against each other.

Roche (2020), on the other hand, studied anti-Chinese sentiments; he has claimed that by highlighting the Chinese eating habits, their unhygienic lifestyles, and bats images, white supremacists tried to build stereotypical images of the Chinese. Moreover, there is a great quantity of work available in newspapers that describes on-going references of anti-Chinese sentiments in the first wave of Covid-19 (Rafi, 2020). This kind of coverage sows the seeds of hatred for the Chinese, as people start looking at the Chinese as a source of the virus. It is understandable that people feel fear especially when there is no cure especially at the beginning of any virus outbreak, but unfortunately, such responses led to discrimination against the Chinese community all over the world (Roche 2020; Rafi, 2020). 
When we witness fear, as an autonomous potential, posing threats to society, we immediately run to see its possible negative impacts on society, but there are hardly any efforts such as Rafi (2020) and Cap (2017) to address the linguistic causality that produces xenophobia. This study took a different conceptual framework just like Rafi (2020) and Cap (2017) to explore linguistic/discursive themes, emerged from coding the data into different categories. Unlike Rafi (2020), this study used a different methodology, a multimodal analysis, which included editorial articles of English newspapers from four different countries for the generalization of the findings. Lexical choices and pictures from these articles were taken for analysis. To support the evidence, public response on these articles were also taken to find out correlation among the discursive themes.

\section{Theoretical framework}

This section involves the theoretical underpinning of Van Dijk's Socio Cognitive Discourse Analysis Model (2009) and Kress and Van Leeuwen's (1996) Social Semiotic Approach to study multimodal discourse of the selected English language newspapers. For this study, I have used triangulation of both approaches for my findings. Social Cognitive Discourse Analysis is a novel approach situated within Critical Discourse Analysis to link discourse and social and individual cognitions. According to Van Dijk (1991), press has the most significant role in making a context to shape an ethnic event, usually lead by the leading group. It is an approach built on Social Constructionism Theory, that exhibits socio-political realties are constructed by the social beings (Berger \& Luckman, 1966). Particular social context shapes a discourse by picking particular syntactic structures, indexical expressions, themes, specific propositions and its relation with pronouns, distinct metaphors, particular evidential, and frames. It leaves audience to presuppose and implicate a particular ethnic event. Furthermore, according to Van Dijk (2009), a speaker/writer knows which language tools are required for on-going event and for what purpose. Thus, for the production of discourse, a writer, before applying semantic model, may apply context model to plan what, where, when, with whom, how, why, and for what purpose he/she is writing or speaking. Moreover, he declared that the language use is affected by the linguistic and discursive knowledge system that is shaped by the social order around.

On the other hand, Social Semiotics is an approach to analyse discourse which examines communication modes in a particular setting. These modes of communication are not affected by the language rules and patterns, but because of what they can fulfil in a social setting. Signs, including words and pictures are used with a specific aim to achieve interpersonal and institutional powers. According to Kress and Van Leeuwan (1996), semiotic resources provide options for communication that offer historically and socially influenced communicational modes. According to this approach, semiotic choices are available every time, speakers choose particular options for accomplishing their tasks. Semiotic choices are not fixed, but they are carriers of senses that can make meaning with other choices. This theory points towards the study of (a) how do speakers perpetuate particular text and (b) how do they interpret it (Kress \& Van Leeuwan, 1996; Kress, 2009)? Since this study has definite limitations, that is why, it did not include macro linguistic aspects (social, political and cognitive) of Socio-Cognitive Discourse Analysis, it only studied the micro linguistic aspects (meanings) to study discourse of Sinophobia by including one conceptual aspect from Social Semiotic approach, that is, picking up certain semiotic choices over others. 


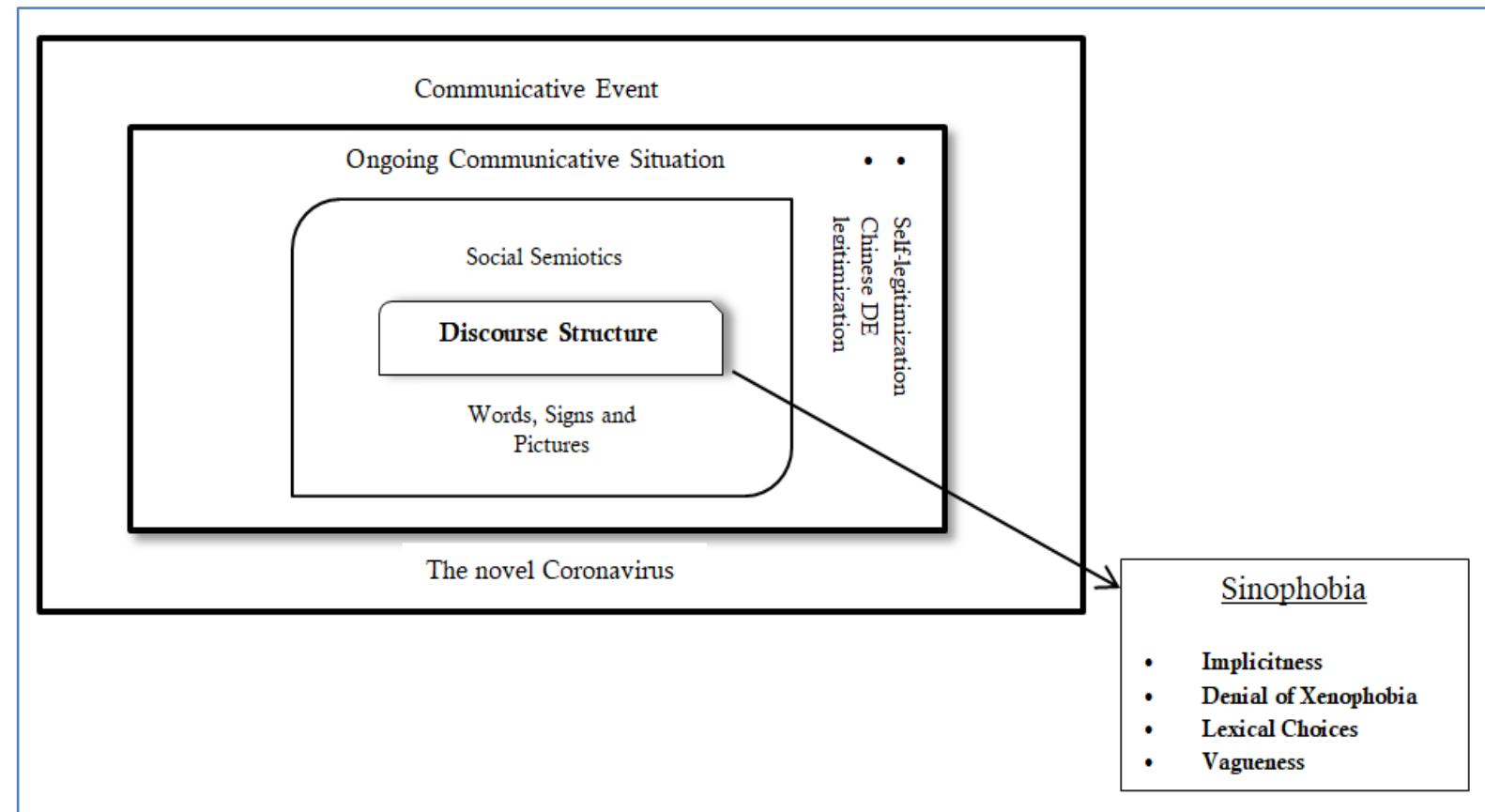

Figure 2: Theoretical framework

\section{Methodology}

This is qualitative research. The qualitative data was based on editorial articles published in "New York Times", "The Guardian", "The Express Tribune" and "The Japan Times" from $31^{\text {st }}$ December to $10^{\text {th }}$ February 2020. These newspapers were selected on the notion that they are available online and the public has access to comment under these online available articles. Moreover, these newspapers are widely read in the respective countries. All the editorial articles are mentioned in [1a-i] were taken purposively on the notion that an article must have maximum online public comments, from all other published articles in these newspapers during the period of the study. Public comments related to anti-Chinese sentiments under the articles were selected for analysis. Since all the editorial articles were written through the lenses of the Covid-19, words and graphics both were picked to analyse discursive themes, used by the selected English language newspapers. Through the early analysis of the data, I have found that visuals used in Express Tribune and The Japan Times were the real representations of editors as they used their own pictures. The New York Times and The Guardian took visuals from other sources including Getty Images, Reuters, PA media, and Barcroft Media. Moreover, since all articles were taken from online sources, 30 public comments were collected to find discursive themes and their connection to the semiotics used in the articles. 1(a-e) illustrates the list of selected articles of English language newspapers and their headlines.

[1]

a) Here Comes the Coronavirus Pandemic (NY Times)

b) SARS Stung the Global Economy. The Coronavirus Is a Greater Menace (NY Times)

c) Coronavirus on the loose (The Tribune)

d) Emergent infections: what to do? (The Tribune)

e) The Guardian view on the coronavirus outbreak: leadership is required (The Guardian)

f) The Guardian view on the new coronavirus be alert, not afraid (The Guardian) 
g) The Observer view on the coronavirus outbreak (The Guardian)

h) COVID-19: Preventing a medical system breakdown (The Japan Times)

i) Use the coronavirus crisis to promote teleworking (The Japan Times)

However, the purpose of this research is not to label newspapers as carriers of discrimination, but to highlight their use of semiotics that describes anti-Chinese sentiments. Moreover, the interpretation of texts, pictures, and their messages was done through rigorous process of codifying the data and interpreting the emerged themes by staying neutral to my best. Interpretation was finalised by linking texts, pictures, and their messages together to see common patterns in between them, so that they could be put into the emerged themes.

Figure 1: Discourse of Sinophobia

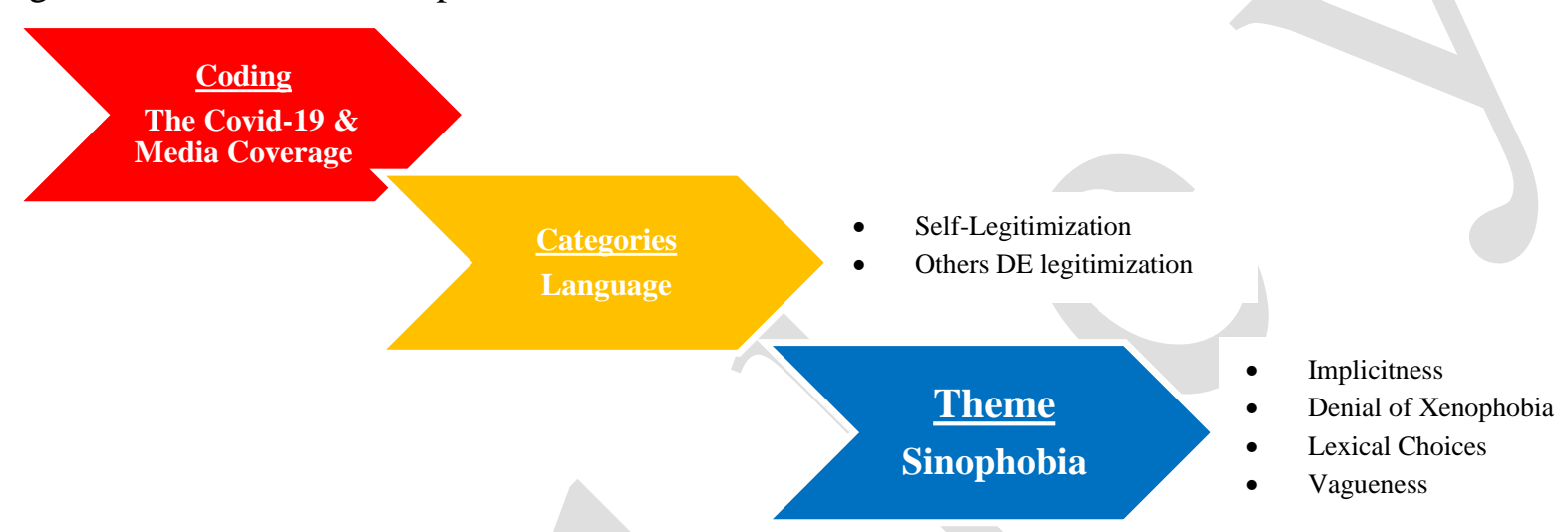

\section{Analysis and discussion}

The spread of the virus tested our mutual and intellectual consciences. The role of English language newspapers in creating anti-Chinese sentiments is significant as millions of readers confront English language newspaper reporting that shapes their minds about Covid-19 which Van Dijk (2014) named as mental models. Language and reporting play a substantial role in building positive self-legitimization and negative delegitimization of others as Marko (2013) and Cap (2017) believe that stereotyping and categorization are important in creating good-self and bad out-group. Van Dijk (1991) believes that language use of media is not neutral, but intentional and ideological; where hegemonic links affect editorial policies, lexicon selection, and aspects of meanings which are used to build a stereotypical negative portrayal of others on the basis of fear.

\subsection{Implicitness/implied meanings}

According to Van Dijk (1991), the most powerful tool in critical discourse analysis is implicitness or indirectness through words and propositions. Knowledge, principles, and mental models of newspapers affect the description of any ethnic event, for that, newspapers use implicitness for shared comprehension of text between the writers and audience (Van Dijk, 1991), as [2a] links vague human awareness to the existing threat of the spread of the Covid19. By highlighting the Chinese eating habits of bat or snakes, the Chinese community is declared to be the cause of the spread of the Covid-19 pandemic as it can be seen in [2c] and [2e] where the Chinese fresh meat markets were criticized that it would cause 50 million people to suffer from pandemic. Roche (2020) claims that through images of bat eating, the virus' 
etiology has been described in such a way that it ultimately raises anti-Chinese sentiments, although according to Gralinski and Menachery (2020), samples collected by WHO have not revealed any association of a particular animal in the spread of the Covid-19 during the period of the study.

The newspaper coverage as in [2c] has compelled the public to relocate their mental models as they are asking people to think that eating fresh meat is one of the causes of virus emergence. [2c] and the response of participant 3 present such scenarios. Participant 2 commented, "Treat nature better China/Animals especially in this case." Participant 15 believes that the virus has come from the animal trading centre in Wuhan, people are walking on the Lunar Calendar New Year holidays. Participant no. 17 considers China's selling of meat as the real issue behind all the hassle that needs to get barred in other regions of the world. Moreover, participant no. 21 blamed the Chinese exploitation and weak regulation of wild meat in the passing years which has caused the emergence of a virus outbreak. The social/public rhetoric on the selected English newspaper goes to the extent that demands China to be punished for its carelessness and concealment of information as the country endangered the lives of many as can be seen in the response of participant no. 24 who says, "All I want is for China to be punished for their sloppy health standards for the third time in 20 years..." which is a replication of the selected English newspaper language that declared the Chinese weak health system to be the cause of virus spread all around the world as it can be seen in [3b] and [3c]. Hence, the language of the selected English newspaper to name China as the manufacturer of the virus is well replicated by the public.

The Chinese were considered to be the producer of many deadly viruses and the Chinese officials found concealer of information of the spread of the virus in the past as seen in [2d] and [2f], that implies, the Chinese censored all information about the spread of viruses in the past and the situation is somehow no different this time either, yet there is a minor difference that the Chinese are more open this time to share the information with the world community. This kind of lexical choice has been replicated by the public as participants no. 18 and 28 started believing that China's underreporting has caused the damage, where the Chinese officials censored all the miseries of the patients, yet it was so hard to conceal that the officials had to have shared the information. Participant no. 04 blamed the Chinese centrally controlled government for censorship of reliable information to the common men. Hence all implied information is perpetuating hatred for the Chinese community and mistrust of the Chinese government concurrently. Moreover, the mainland of China was believed to be the danger zone as [2b], [2c], [3b], [3e], [4b], and [5c] have mentioned the strict travel ban to the mainland of China. Moreover, figure 3 shows that only the Chinese were visualized in the selected English language newspapers to report about the spread of the Covid-19 and its impacts on the whole world which is making the Chinese an ethnic community.

China is among the world's fastest-growing countries, but since it is believed that the outbreak has started in the city of Wuhan, China, the country is under great criticism for revealing a virus. [3c] has illustrated that the outbreak has exposed China's shortcomings; it means that the country is not capable to restrict the virus. Furthermore, the selected English newspapers label the virus as incurable which is meant to kill people as seen in [2e] which implies China's carelessness has threatened many lives and the economies of the world that are supported by the evidence used by the English newspapers' texts in [4b]. Such semiotics compels the public to change their mental models as the language of media is well replicated in the public discourse 
circling the coronavirus outbreak. The response of participant no. 04 is significant, as he labelled the Chinese' inability to construct an agency like CDC to work on human health and disease issues. He says, "Although China is playing aggressively on the world stage, yet its governance system did not allow building agencies like CDC and FDA to protect the lives of people and control food and drugs". [3c] has mentioned China as an epicentre of the Covid-19, where it is initially emerged.

[2]

a) "Our vague awareness" (The Guardian view on the new coronavirus: be alert, not afraid-The Guardian)

b) All patients who had been in China." (The Guardian view on the new coronavirus: be alert, not afraid-The Guardian)

c) "In this case, scientists think it is likely to have come from bats or snakes in a live food market in the Chinese city of Wuhan" (The Observer view on the coronavirus outbreak-The Guardian)

d) "This time the authorities have been more open" (The Observer view on the coronavirus outbreak-The Guardian)

e) "Affecting more than 50 million people." (The Observer view on the coronavirus outbreak-The Guardian)

f) "It is essential that Chinese authorities at all levels are open about this outbreak, as well as assiduous in tackling it." (The Guardian view on the new coronavirus: be alert, not afraid-The Guardian)

a) "With the death toll already soaring past 500 and thousands affected" (Coronavirus on the loose-The Tribune)

b) "China, the epicentre of the spreading virus" (Coronavirus on the loose-The Tribune)

c) "Several cases of suspected coronavirus have surfaced in the past week causing an alarm and exposing the shortcomings in the country's health system and disaster management." (Coronavirus on the loose-The Tribune)

d) "Pakistan had initially suspended flights from China (Coronavirus on the loose-The Tribune)

e) "Novel Coronavirus from Wuhan continues to grip the world... Pakistan is no exception. (Emergent infections: what to do? -The Tribune)

[4]

a) "Another deadly virus" (SARS Stung the Global Economy. The Coronavirus Is a Greater Menace-NY Times)

b) "All of this could play havoc with businesses that depend on China for components" (SARS Stung the Global Economy. The Coronavirus Is a Greater Menace-NY Times)

c) "The spread of the incurable virus" (Here Comes the Coronavirus Pandemic-NY Times)

d) "But, as Covid-19 makes clear, much more is still needed" (Here Comes the Coronavirus Pandemic-NY Times)

[5]

a) "Companies should allow their employees to work from home as much as possible" (Use the coronavirus crisis to promote teleworking-The Japan Times) 
b) "COVID-19 has shifted from a prevention of cross-border infections" (COVID-19: Preventing a medical system breakdown-The Japan Times)

c) "Infections among people who have no recent history of travel to China." (COVID-19: Preventing a medical system breakdown-The Japan Times)

\subsection{The Denial of Xenophobia}

As mentioned before, discrimination and prejudice are considered immoral or sometimes illegal in our society. In such a scenario, the approach of positive self-claim is essential, and this strategy is well used by only 'The Guardian' and 'The NY Times'. According to Van Dijk (1991), the strategy of positive self-presentation is usually used to delegitimize others. Later on, the claim of Van Dijk got support from Cap (2017) that media texts are used to provoke self-good and others-evil to fulfil certain socio-political goals. What we witness here, is similar to the claims of Van Dijk (1991) and Cap (2017). In [6a] and [6b], China's role in the world is acknowledged which is referred to as 'admission' in linguistic terms and then presented the negative side to delegitimize its role in spreading the Covid-19 by using the linguistic technique of 'othering' as Mahr (2020) claimed that the Chinese culture and its eating customs were targeted even before the scientists can fix the origin of the virus outbreak. It is well-replicated in the social rhetoric of the participants as participant no. 29 says, "China to stop their so-called wet markets where they are selling exotic live animals that they then cook and eat, apparently sometimes eat raw".

In [6c], the strategy of positive self-claim is again deployed that they want mutual trust between the countries to break the damage of the Covid-19, and then the denial of xenophobia is used to self-legitimize in [6d]. Roche (2020) believes that media usually lead by 'White Supremacist' accept the existence of Sinophobia but deny its importance which Cohen (2013) termed as 'Implicatory Denialism' that does not talk about denials of facts yet denies their socio-psychological significance. Therefore, the use of implicatory denialism for the prophecy of Sinophobia supports discriminatory speech which permits the sufferings of racialized communities to be continued (Roche, 2020). Yet in another example, newspapers tend to have a great impression on their readers for that they praise others first and then highlight negative images to delegitimize others as in the case of China's efforts to curb down the virus has been acknowledged and then the Chinese officials are blamed to hide the outbreak of the virus which resulted in deaths of 800 people as analysed in [6f]. Jennifer Saul (2019) named such a pragmatic strategy as 'fig leaf which first uses the linguistic strategy of denialism through cherishing the target and then contributes to the atmosphere of discrimination against the objects'. Overall, rhetorically, the implicit use of contrast between the good 'us' who are sharing the information and acknowledging the efforts of China to clamp down the spread and negative 'them' who are hiding information from the world and being the cause of the outbreak, this can be seen in $[6 \mathrm{~g}]$.

So, the international English language newspapers have labelled the Chinese consumption of bushmeat as the cause of the coronavirus outbreak by using the pragmatic technique 'others' DE legitimization' as it can be seen in [2c] and the responses of participants 17, 19, and 29 who believe that the consumption of the wildlife has become the reason of the coronavirus' outbreak. Seay and Dionne (2014) found similar descriptions against the African countries as they believe that while the world organizations were busy finding out the origins of former viruses, which had apparently emerged from Africa, the media evoked anti-African sentiments 
and labelled them as dirty and disease transmitters. We found something similar in the first wave of Covid-19.

a) "China has evolved into a principal element of the global economy, making the epidemic a substantially more potent threat to fortunes." (SARS Stung the Global Economy. The Coronavirus Is a Greater Menace-NY Times)

b) The whole world depends on as a manufacturing workshop

c) To limit the damage, trust and information are of the essence (SARS Stung the Global Economy. The Coronavirus Is a Greater Menace-NY Times)

d) This is all the more important when xenophobic outbursts have been reported (The Observer view on the coronavirus outbreak: leadership is required -The Guardian)

e) China's response stands have won it international plaudits" (The Observer view on the coronavirus outbreak: -The Guardian)

f) 800 deaths worldwide might have been averted had China provided more timely information." (The Guardian view on the new coronavirus: be alert, not afraid-The Guardian)

g) The Chinese authorities did try to clamp down outbreak, but many markets continue to flourish. (The Observer view on the coronavirus outbreak: -The Guardian)

\subsection{Lexical choices/ repetitions}

From figure 4 it has been found out that the English newspaper discourse on the Covid-19 in the first wave mainly focuses on China's role in spreading the virus as the name of the country has been used repeatedly in the articles in phrases such as "China, the epicentre of the spreading virus". According to Van Dijk (1991), linguistic repetition is mostly used to describe the negative impacts of an ethnic affair in abnormal circumstances. Through repeated lexical choices including death, spread, infection, health, and outbreak have further intensified the impact of the virus and eventually caused anti-Chinese sentiments, since all the articles mentioned 'China' as an epicentre of the virus. Schild et al. (2020) claimed that disturbing content including conspiracy theories and hate speech are used to target the Chinese in the outbreak of the Covid-19. Moreover, Mahr (2020) claimed that words and images used to describe the virus are perpetuating problematic assumptions about China and the Chinese community all over the world.

Zhang (2008) claims that China is a country that is not liked by the Western world, and because of its economic hegemony, anti-Chinese sentiments are prevailing in the media texts (Silver et $a l ., 2019)$. China has been described in terms of a disease generator engine. These anti-Chinese remarks are further driven by highlighting the Chinese eating habits and labeling them in a biased manner. For example, the selection of a phrase such as 'wet market' instead of 街市 (jiē shì) which means street markets has shown that authors' common written expressions are antiChinese as 'wet' here is connected with both 'full of blood' and 'unsanitary conditions'. It is fully replicated by the audience as they have started writing the same lexical choice, for instance, the responses of participants no. 29 and 30 demand, "China to stop their wet markets where they are selling exotic live animals". Also, participant no. 19 highlighted the Chinese custom of using animals for medicine must be discouraged by the new generation as it has no medical benefits other than endangering human life. Such lexical choices are contextualizing and producing stereotypical images about the lives of the Chinese. 


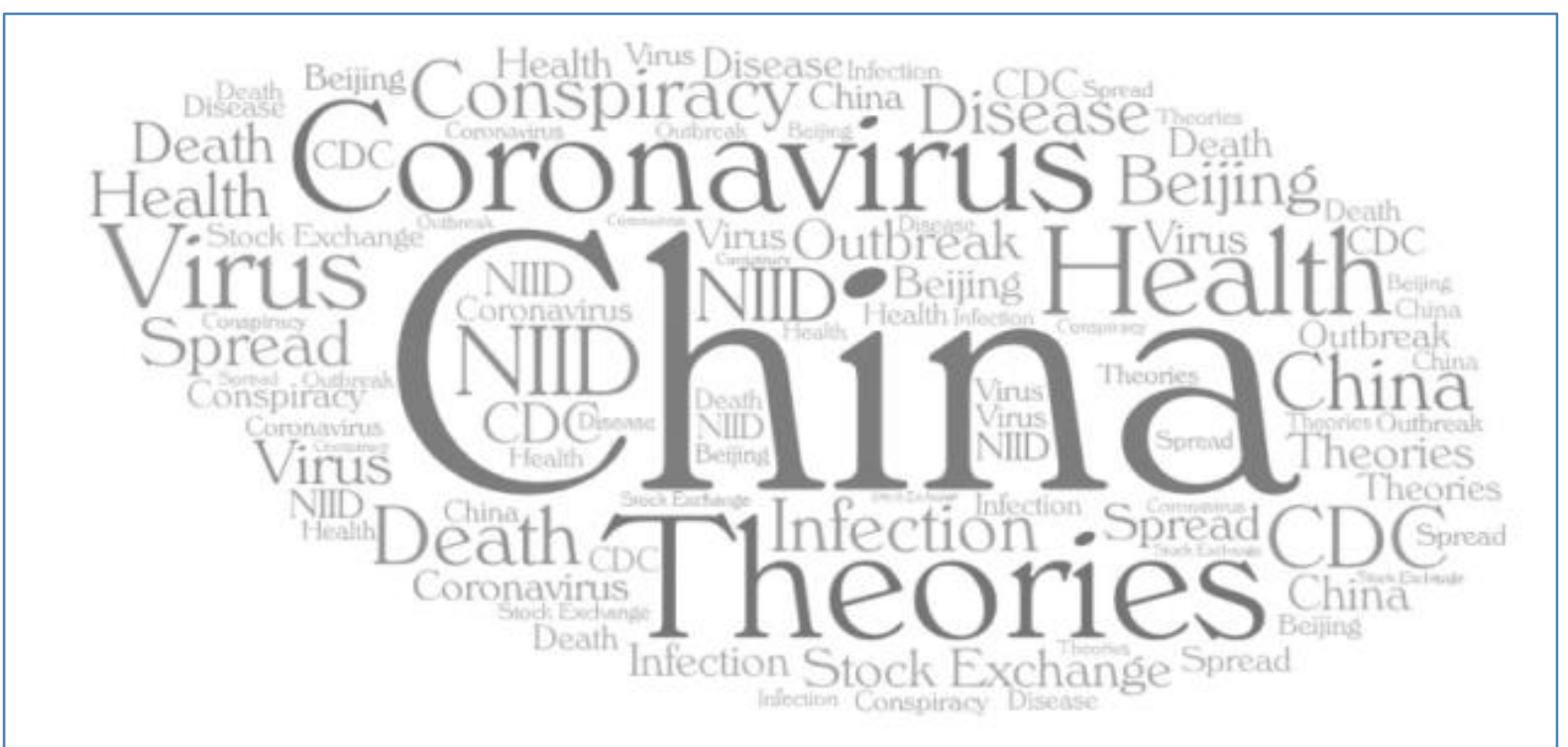

Figure 3: Word Cloud of most frequent words used to report the Covid-19

\subsection{Vagueness}

Van Dijk (1991) believes that the press has the tendency to use nominalization to obscure the fact "who exactly is responsible for a negative act?" Vagueness is a semantic category, often uses to conceal the responsibility of negative actions through two key terms 'degree of abstraction and 'relative degree of completeness'. [6a to $6 \mathrm{~m}$ ] has also shown that vagueness is used to conceal the responsibility of negative actions especially when the selected English language newspapers label China as the manufacturer of Covid-19. Through the analysis, it is observed that all articles have one thing in common, that is the use of institutional names or common nouns rather than the actual person who is being quoted. [6b] has shown the scientists' observation about the eating habits of the Chinese, which are considered to be the cause of the Covid-19 spread and hence associated with anti-Chinese sentiments. Moreover, in reporting about the viruses, the Chinese are blamed for the concealment of information as we can see in [2c]. Moreover, it can be claimed here that all blame game is reported through vague reporting i.e., using unknown sources to report the events.

a) "Health experts say..." (Here Comes the Coronavirus Pandemic-NY Times)

b) "Scientists think it is likely to have come from bats or snakes in a live food market in the Chinese city of Wuhan" (The Observer view on the coronavirus outbreak: -The Guardian)

c) "Public health officials told citizens there was nothing to worry about" (The Observer view on the coronavirus outbreak: -The Guardian)

d) "Global health experts warned that the ensuing outbreak was a harbinger of things to come Scientist later traced" (Here Comes the Coronavirus Pandemic-NY Times)

e) "Returning from a long holiday for the first time since the coronavirus's threat became clear, Chinese investors sent shares in China down about 8 percent on Monday." (SARS Stung the Global Economy. The Coronavirus is a Greater Menace-NY Times)

f) "The trade war waged by the Trump administration has prompted a partial decoupling of the United States and China, the two largest economies on earth." (SARS Stung the Global Economy. The Coronavirus is a Greater Menace-NY Times) 
g) "While authorities worldwide have taken extreme measures to curtail the spread of the virus, the response at home has been too slow and too disappointing." (Coronavirus on the loose-The Tribune)

h) "Additionally, callousness from health authorities and the lack of facilities needed to tackle suspected coronavirus patients" (Coronavirus on the loose-The Tribune)

i) "In the last few days, there have been some messages from the ministries of health, and the National Institutes of Health, but a lot more needs to be done The World Health" (Emergent infections: what to do?-The Tribune)

j) "Organization will hold an emergency meeting" (The Guardian view on the new Coronavirus: be alert, not afraid-The Guardian)

k) "Officials covered up the problem for months..." (The Guardian view on the new Coronavirus: be alert, not afraid-The Guardian)

1) "To prevent a rapid increase in domestic infections of the COVID-19 coronavirus, according to a panel of infectious disease experts who are advising the government" (COVID-19: Preventing a medical system breakdown-The Japan Times)

\section{Conclusion}

The newspaper coverage of the Covid-19 involved millions of readers who daily confront the semiotics choices that shape their opinions. Semiotic choices deployed by the English language newspapers have done a significant job in creating anti-Chinese sentiments by highlighting their good and negative image of the Chinese. By highlighting the Chinese eating of snakes or bats, unsanitary conditions of fresh meat markets in China, and termed them as 'wet markets', the selected English newspapers have created a wave of anti-Chinese sentiments. The textual forms are well supported by the visuals for the categorization of Chinese. The Chinese autocratic system was criticized to the extent that they were believed to be the producer of many viruses because of their carelessness. They have also been tagged as a concealer of information of the spread of the Covid-19. Though China is mentioned as an emerging superpower, yet it is criticized for its shortcomings in the field of health which endangered the lives of many. The repeated use of phrases such as "China, the epicentre of the spreading virus" reasoned China to be the cause of the spread of the virus. Just because such reporting without taking advice from concerned authorities such as medical doctors/specialists made China a 'risk society' and the Chinese all over the world a 'risk community'.

All such semiotic choices including lexical and visual are making a negative stereotypical image of the Chinese that the Chinese are dirty, have an unhygienic way of eating and living, producers of previously occurred virus outbreaks, currently the producer of the Covid-19, and concealer of information. Such reporting greatly impacts public mental models as they can be seen, using the language of the selected English-language newspapers, the language that perpetuates perpetuating anti-Chinese sentiments. In response to the selected English language newspaper coverage, the public started to share discourse of Sinophobia as they ask China to close their fresh meat markets, build a comprehensive health structure and allow independent voices for reliable information to contain the virus. Public commentaries have gone to the extent that they demand China be punished for their sloppy work. Henceforth, the English newspaper coverage has affected the public discourse which is creating a difficult situation for the Chinese who are facing a great wave of discrimination. I would, therefore, recommend socio-political researchers conduct a study to see the influence of a complicated socio-political setting that shapes or formulate press biases and journalists' opinions. 


\subsection{Delimitations of the study}

Although this study has conducted a detailed qualitative analysis to figure out discourse of fear and eventually Sinophobia, yet it has certain limitations. This study has included 10 editorial articles of English newspapers from $30^{\text {th }}$ December to $10^{\text {th }}$ February and 30 online public comments to draw the findings.

\subsection{Recommendations}

I would, therefore, recommend future researchers including medical anthropologists and social critics to draw an in-depth analysis of discourse of fear and Sinophobia around the outbreak through scaling the overall spread of the virus (quantitative) and its socio-cognitive impacts (qualitative) on public that can be taken through social media comments, face to face interviews or surveys, hence the triangulation of both qualitative and quantitative methods would elicit rich findings for the complex research settings. Moreover, I would also recommend sociopolitical researchers to conduct a study to see the influence of a complicated socio-political setting which shape or formulate press biases and journalists' opinions.

\section{Funding:}

This research received no funding.

\section{Conflicts of Interest:}

The author declares no conflict of interest.

\section{References}

Albader, F. (2020). Coronavirus and the resurgence of Sinophobia. Tsinghua China Law Review, 12(2), 289. http://www.tsinghuachinalawreview.org/articles/1202_Albader.htm

Berger, P. L., \& Luckmann, T. (1966). The social construction of reality: A treatise in the sociology of knowledge. Anchor.

Clarke, V., \& Braun, V. (2014). Thematic analysis. In Encyclopedia of critical psychology (pp. 1947-1952). Springer. https://doi.org/10.1007/978-1-4614-5583-7_311

Cap, P. (2016). The language of fear: Communicating threat in public discourse. Palgrave Macmillan Springer.

Cohen, S. (2013). States of denial: Knowing about atrocities and suffering. John Wiley \& Sons.

Corradi, J. E., Fagen, P. W., Garretón, M. A., \& Merino, M. A. G. (Eds.). (1992). Fear at the edge: State terror and resistance in Latin America. University of California.

Gralinski, L. E., \& Menachery, V. D. (2020). Return of the Coronavirus: 2019nCoV. Viruses, 12(2), 135. https://doi.org/10.3390/v12020135

Hua, J., \& Shaw, R. (2020). Corona virus (Covid-19) "infodemic" and emerging issues through a data lens: The case of China. International Journal of Environmental Research and Public Health, 17(7), 2309. https://doi.org/10.1016/j.envpol.2017.12.006 
Kress, G. R., \& Van Leeuwen, T. (1996). Reading images: The grammar of visual design. Psychology.

Kress, G. (2009). Multimodality: A social semiotic approach to contemporary communication. Routledge.

Mahr, D. (2020). The cultural construction of the 'Bizzare'. Disentangling Sinophobic Language in media and science during the COVID-19 Epidemic (\#WitnessingCorona). https://www.medizinethnologie.net/the-cultural-constructionof-the-bizzare/

Marko, D. (2013). Fear control in media discourse. Southeastern Europe, 37(2), 200-219, https://doi.org/10.1163/18763332-03702005

Rafi, M. S. (2020). Language of COVID-19: Discourse of fear and Sinophobia. Social Sciences \& Humanities Open. http://dx.doi.org/10.2139/ssrn.3603922

Roche, G. (2020). The epidemiology of Sinophobia. Made in China Journal. https://madeinchinajournal.com/2020/02/17/the-epidemiology-of-sinophobia/

Saul, J. (2019). What is happening to our norms against racist speech? Aristotelian Society, 93(1), 1-23. https://doi.org/10.1093/arisup/akz001

Seay, L., \& Dionne, K. Y. (2014, August 25). The long and ugly tradition of treating Africa as a dirty, diseased place. The Washington Post. https://www.washingtonpost.com/news/monkey-cage/wp/2014/08/25/otheringebola-and-the-history-and-politics-of-pointing-at-immigrants-as-potential-diseasevectors/

Schild, L., Ling, C., Blackburn, J., Stringhini, G., Zhang, Y., \& Zannettou, S. (2020). "Go eat a bat, chang!": An early look on the emergence of sinophobic behavior on web communities in the face of covid-19. arXiv preprint arXiv:2004.04046.

Silver, L., Devlin, K., \& Huang, C. (2019). US views of China turn sharply negative amid trade tensions. Pew Research Center. https://www.pewresearch.org/global/wpcontent/uploads/sites/2/2019/08/Pew-Research-Center_U.S.-Views-of-ChinaReport_2019-08-13.pdf

Van Dijk, T. A. (1991). Racism and the press. Routledge.

Van Dijk, T. A. (2009). Society and discourse: How social contexts influence text and talk. Cambridge University.

Van Dijk, T. A. (2014). Discourse and knowledge: A sociocognitive approach. New Cambridge University.

Yong, C. (2020). UK police release images of 4 men linked to COVID-19 racist attack on Singaporean student in London. The Straits Times Singapore. https://www.straitstimes.com/singapore/uk-police-release-images-of -4-men-linkedtocovid-19

Zhang, C. (2008). From Sinophilia to Sinophobia: China, history, and recognition. Colloquia Germanica, 41(2), 97-110. https://www.jstor.org/stable/23981714

Zhao, I. (2020). Coronavirus has sparked racist attacks on Asians in Australia. ABC News. https://www.abc.net.au/ news/2020-02 01/coronavirus-hassparked-racist-attacks-onasian-australians/11918962

Zheng, Y., Goh, E., \& Wen, J. (2020). The effects of misleading media reports about COVID19 on Chinese tourists' mental health: a perspective article. Anatolia, 31(2), 337-340. https://doi.org/10.1080/13032917.2020.1747208 